\title{
The Mediating Role of Organizational Culture on the Relationship between Employee Performance and Antecedents in the Hotel Sector
}

\author{
Ghaith Abdulraheem Ali Alsheikh*, Mutia Sobihah Binti Abd Halim, Maysoon Shafeeq \\ Ahmad Alremawi and Abdul Malek Bin A Tambi
}

\author{
Universiti Sultan Zainal Abidin (UniSZA) / Faculty of Economics \& Management Sciences, Malaysia
}

\begin{abstract}
Hotel managers face more risks and complexity in their work environment compared to their manufacturing firms' counterparts owing the unique service characteristic offered by hotels. The hotel managements' budgetary participation and their leadership styles, commitment quality management practices (QMPs) in terms of communications can all assist them in tackling the uncertain and risky environment for better performance of jobs. This article defined and measured leadership style, organizational commitment, quality management practices (QMPs) and their impact on organizational performance, and examined the moderating role of organizational culture on the above relationship. The article conducted an analysis of the empirical studies and models that related leadership style, organizational commitment, quality management practices (QMPs), organizational culture and performance. It primarily aimed to illustrate the conceptualization, measurement and examination of the different concepts. Following the analysis of literature, the findings showed that leadership style, organizational commitment, quality management practices (QMPs) and organizational culture significantly effects various hotel processes, employees and performance. The article also provided a description of the various dimensions of the leadership style and it found that with committed employees with norms and values consistent to those of the organization, the performance of the hotels can increase towards achieving it goals. This article suggests that the balanced scorecard (BSC) be used as a tool to measure performance in the performance management system. It also suggests that future studies focus in this area to shed light on the nature and the ability of variables to influence hotel performance. Hotel management and leaders are suggested to form robust quality management practices within the hotels to enhance its overall performance.
\end{abstract}

Keyword: Leadership style, commitment, quality management practices (QMPs), culture, performance, hotel.

\section{INTRODUCTION}

The dynamic competition among hotels and the ongoing pressure to perform better stemming from the saturation in the market call for the need to enhance the performance of hotels in the hotel industry (Assaf, Josiassen \& Cvelbar, 2012; Pavia, Grzinic \& Floricic, 2014; Wang, Chen \& Chen, 2012). With the continuous expansion of the hotel brands in the international arena, the selection of an attractive tourist destination that will provide the best returns has become the focus of most debates and contentions concerning issues faced by the hotel providers around the globe (Yang, Wong \& Wang, 2012). Despite the extensive studies conducted to investigate the importance of the characteristics of the destination in light of the decision making process, there is still lack of research that identify and rank the determinants of hotel performance. To this end, Assaf and Jossiassen (2016) recently stressed on the fact that while over 50 empirical studies have attempted to measure and conduct a comparison among the international hotels' performance, the determinants of such hotel performance in the tourism sector have been confined

*Address correspondence to this author at the Universiti Sultan Zainal Abidin (UniSZA) / Faculty of Economics \& Management Sciences, Malaysia; Tel: 0060182601251; E-mail: aligaith89@yahoo.com to only a few studies. This holds true in the context of Jordanian hotel sector.

Like most of the Middle Eastern tourism destinations, Jordanian tourism sector is quite significant to the economy owing to its contribution to the same. More specifically, the accommodation industry, as an element of the tourist product is core to identifying the overall tourism experience. A considerable time is spent by travelers in hotels, where they sleep, relax and do business. In this regard, hotel guests are expected to complain when dissatisfied, but in actuality, only a small proportion of guests complain to management in this situation (Dincer \& Alrawadieh, 2017).

This research has its basis on the notion that guests that avail Jordanian hotels may experience more burden when have to draw up complaints. This is due to the language barriers, traveler's expectations and inaccurate/accurate information concerning the host culture, and because Jordan is located in a region that is considered as unstable. Hence, hotel performance review in this case becomes essential during this period to determine the sector's problems.

Moreover, the low rate of occupancy in hotels may not be related merely to the factors of demand and 
supply. In the context of luxury hotels, the low rates of occupancy are not likely to be related with the introduction of the informal accommodation sector (Zervas, Proserpio \& Byers, 2014). The Jordanian accommodation sector is evidently faced with challenges that hinder its achievement of high occupancy rates. The scenario is such that by early 2015, four of the five-star hotels in Jordan - Petra were forced to foreclose owing to the very low rates of occupancy (Dincer \& Alrawadieh, 2017).

This paper contributes by identifying the major factors leading to hotel performance from the viewpoints of employees' in luxury hotels. The study sheds light on the performance of hotels in managing their reputations based on their employees' responses and perceptions. The identification of the factors leading to the employees' performance in Jordan can also provide information in comprehending the situation in the neighboring nations like Egypt and Lebanon that offer similar tourist products/services as well as patterns of culture (language, religion and traditions). This paper is expected to obtain the attention of hotelier leaders and government decision-makers to the employees take on how to provide suitable services to hotel patrons.

\section{LITERATURE REVIEW}

\section{Employee Performance}

Any organization would be unable to achieve its goals successfully through the hard work of a single or few individuals in the company. In other words, all employees have to perform well to achieve successful performance. Performance, in fact, is a concept that has multiple dimensions that companies have to be aware of in terms of their effects on strategies and goals. To this end, employee performance has significant contributions to the core running of the organization. Employee performance can be gauged through their productivity and efficiency as their growth and performance is a reflection of the performance of the organization. This brought about the understanding of organizations concerning the importance of their employees as assets because without employees, an organization cannot accomplish its goals (Mwita, 2000).

The concept of employee performance refers to the level and quality of effort, cooperation, commitment, lateness and absenteeism, and compliance of employees with the organization's standards (KuranchiMensah \& Amponsah-Tawiah, 2016). Similarly, Yuan and Woodman (2010) described it as the employees working to achieve specific work that leads to positive outcomes and behaviors. Meanwhile, McConnell (2003) stated that employee performance is individual worker's achievement and contribution that is quantifiable. It is a concept with complex aspects that is susceptible to the effects of several variables (Popovich \& Brizius, 1998), that include age, gender, employee recognition and job satisfaction (Fort \& Voltero, 2004; Wright \& Bonett, 2002).

\section{Leadership Styles}

There are several leadership styles, with each bringing about different outcomes that directly or indirectly impact the employees' attitudes and behaviors. Literature shows that transformational leadership behavior is positively related to outcome variables, whereas transactional leadership behavior is often negatively related to long-term performance. Prior studies also evidenced that transformational leadership positively relates to the self-efficacy, motivation, creativity of employees and organizational performance (e.g., Bronkhorst, Steijn \& Vermeeren, 2015; Jyoti \& Bhau, 2015; Newland, Newton, Podlog, Legg \& Tanner, 2015).

In contrast, transactional leadership has been evidenced to improve job satisfaction and organizational identification compared to its transformational counterpart (Epitropaki \& Martin, 2005; Zhang, Waldman, Han \& Li, 2015). Moreover, transformational leaders assist workers to adapt to the changes in the organization (Bommer, Rubin \& Baldwin, 2004). In sum, transformational and transactional leadership styles affect employees' attitude towards their leaders, their job performance and ultimately, the productivity of the organization they work in.

Considerable portion of literature evidenced the impact of leadership style on job performance (e.g., Ariyabuddhiphongs \& Kahn, 2017; Elbaz \& Haddoud, 2017; Gao, 2016; Wahab, 2016).

\section{Transformational Leadership}

One of the top popular theories in the field of leadership is transformational leadership. It has been deemed to be an important topic in leadership for over two decades (Bruch \& Walter, 2007; Keskes, 2014). Such interest and focus is compounded by the notion that transformational leadership could result in positive relationships with employees, performance motivation, 
commitment and effective leaders. Added to this, this style of leadership is robust throughout conditions and it can be applied in various cultures unlike other leadership styles (Ivey \& Kline, 2010). Transformational leadership is also related to individual outcomes that are of significance to the successful running of organizations like creativity, satisfaction, performance, organizational commitment, work withdrawal, task performance and organizational citizenship behavior as well as absenteeism (Cheung \& Wong, 2011; Omar, 2013).

Several authors have also evidenced the impact of transformational leadership style on job performance (e.g., Bacha, 2014; Chu \& Lai, 2011; Herman \& Chiu, 2014; Liang \& Chi, 2011; Sani \& Maharani, 2012).

\section{Transactional Leadership}

Transactional leadership style is also one of the alternative leadership styles to transformational style that has been studied by several authors. This leadership style has its basis on the premise of reciprocal leader-follower relationship (Vito, Higgins \& Denney, 2014). It expounds on the relationship between leaders and followers, within which they exchange economic, political and psychological values in exchange for standards of performance (Ravichandran \& Gilmore, 2007). Moreover, transactional leaders enter into a cost benefit economic exchange with their subordinates as the latter's needs (material and psychic) are met in exchange for achieving standard work performance (Sarros \& Santora, 2001). In this leadership style, subordinates are expected to consent to, accept and adhere with the leader's words in to obtain his rewards, praise and resources and to steer clear of his meted out punishments (Liu, Liu \& Zeng, 2011).

In comparison to transformational leadership, transactional leadership concentrates on short-term, daily leadership (Rowold \& Schlotz, 2009), during which leaders requiring information or subordinates with skill-solving skills create a negotiation situation that incurs time as negotiation takes place as opposed to productivity (Vito et al., 2014). It is a more passive leadership style that calls for oversight of deviations, mistakes and errors and rectifying the problems as they arise (Obiwuru, Okwu, Akpa \& Nwankwere, 2011). This leadership type limits the development of the innovative and creative skills of employees and prevents them and the organization from growing (Dai, Dai, Chen \& Wu, 2013).
Significant number of studies has evidenced the impact of transactional leadership style on job performance (Chu \& Lai, 2011; Politis, 2001; Rowold, Borgmann \& Bormann, 2014; Zhang, LePine, Buckman \& Wei, 2014).

\section{ORGANIZATIONAL COMMITMENT}

Researchers have reached a consensus as to the organizational commitment being a determinant of organizational performance. The term organizational commitment is described as the individual's participation and classification with the organization in that there is a societal relationship that links the two (individual and organization) together. Individuals who are highly committed have a tendency to engage in extra role behavior. Moreover, organizational obligation controls such extra role behavior.

More importantly, the top significant and acknowledged definition in literature of organizational commitment is by Meyer and Allen (1984). They provided three dimensions of the term and they are affective commitment, normative commitment and continuance commitment.

Evidence also abounds of the role of organizational commitment on organizational performance; to begin with, Clarke (2006) focused on the commitment and network performance in the healthcare units in the U.K., and revealed that affective as well as normative commitment statistically and significant impacted performance. Moreover, he found affective commitment to positively relate to the performance of the network, but continuance commitment to be negatively so. $\mathrm{He}$ reached to the conclusion that commitmentperformance relationship in networks is complex. In a similar line of study, Abdul Rashid, Sambasivan and Johari (2003) examined 202 Malaysian companies managers and found corporate culture and organizational commitment to be interconnected and they had considerable impacts on performance. Furthermore, a significant proportion of literature indicated that organizational commitment could have an effect on job performance (Navanitham, 2016; Nor Hidayah, 2016).

\section{QUALITY MANAGEMENT PRACTICES (QMPS)}

According to Deming (1986), the system of production and service in an organization has to be continuously enhanced in terms of their quality for performance improvement. One of the derivative advantages of QMPs is that the company employees 
gets highly involved in the design of the effective system and they share on its achievement - such sharing of activity not only generates effective solutions but also motivates the enhancement of organizational performance (Jackson \& Ashton, 1995). In several studies including Feng, Terziovski and Samon's (2007), QMPs were revealed to positively influence the performance of organizations. In sum, QMPs implementation is predicted to lead to enhanced performance of the organization (Kumar, Choisne \& de Groisbois \& Kumar, 2009). Other studies in the field, time and again, showed a relationship between QMPs and organizational performance (e.g., Brah \& Lim, 2006; Saizarbitoria, Landin \& Fa, 2006; Li, Anderson \& Harrison, 2003; Kapuge \& Smith, 2007; Martinez-Costa \& Martinez-Lorente, 2007; Sila, 2007; Yasin, Alavi, Kunt \& Zimmerer, 2004). Therefore, this study expected a positive QMPs implementationorganizational performance relationship.

\section{ORGANIZATIONAL CULTURE}

The concept of organizational culture showed progressive evolution in the mid- $20^{\text {th }}$ century and ever since then, authors have proposed several definitions of the concept, with the commonality among them being organizational culture comprises the values, beliefs and assumptions shared or relayed among the members of the organization (Schein, 2010) - they work as guidance of behavior and facilitate shared understanding (Alvesson \& Sveningsson, 2005; Denison, 1996).

Organizational culture has been extensively examined in literature for its effect on performance. To begin with, Abdullah, Shamsuddin, Wahab and Hamid (2014) revealed a significant role of organizational culture as a compass and level guiding the behavior of the organizational members. Also, Barney (1991) described organizational culture as the primary resource that is utilized by organizations for the maintenance of their competitive advantage and several studies have looked into its impact on performance (Shahzad, Luqman, Khan \& Shabbir, 2012), and some evidenced a significant relationship between the two (e.g., Kemp \& Dwyer, 2001). Despite the varying conceptualizations of organizational culture in literature, the present study adopts the competing values framework (CVF) as it reveals the relationship between the two constructs (organizational culture and organizational performance effectiveness) (Gregory, Harris, Armenakis \& Shook, 2009; Hartnell, Ou \& Kinicki, 2011).
Studies have made use of varying versions of organizational culture and organizational performance to examine the relationship between them. For instance, Gordon and DiTomaso (1992) and Denison and Mishra (1995) revealed that a robust culture positively relates with financial performance in the short run, while Heskett and Kotter (1992) revealed that with adaptive values culture, the long-run performance can be improved rather than the short run. Along the same line of study, Lee and Yu (2004) examined the organizational culture types in terms of their relationships in the context of Singaporean firms and revealed that the organizations cultural strength is interconnected to their performance. Their findings also revealed that cultural elements differentiating organizations from one another positively impact their performance. In Tajeddini and Trueman's (2012) study, they involved 96 businesses in the Swiss hotel industry and found that the dimensions of national culture (power distance, long-term orientation and individualism) positively related with innovation and customer orientation, and innovation and customer orientation positively related with organizational performance. In Taiwan, Chen (2011) also found that a customer-focus strategy in organizations assist in achieving long-term profitability. Their results are consistent with prior studies that promoted the customer orientation view as the culture of the organization and argued that for long-term performance, a market culture is a must that requires recruiting well-qualified and experienced workforce (Desphande, Farley \& Webster Jr., 1993).

Extant literature also recommended the examination of organizational culture's direct relationship with performance (e.g., Elnihewi, 2015; Umrani, 2016; Wunderlich \& Beck, 2017) and the moderating role of organizational culture on the quality management practices-performance relationship (Romle, 2014). This paper examines organizational culture's moderating role in the context of Jordanian luxury class hotels.

\section{THEORETICAL FRAMEWORK}

This article aims to determine the relationship between leadership style, organizational commitment, quality management practices and hotel performance, with the moderating role of organizational culture. An analysis of literature concerning the sources and causes of public sector organizational performance, highlights various theories. In this article two dominant perspectives are selected as they are aligned with the study objectives and framework. They are the 
resource-based view (RBV) theory and the systems theory. Detailed explanation of the two is provided in this section with justification of their selection.

First, the resource-based view (RBV) theory posits that competitive advantage and performance outcomes stem from firm-specific resources and capabilities that are costly to imitate by the rivals (Barney, 1986; Barney, 1991; Rumelt, 1987; Wernerfelt, 1984). Such resources and capabilities function as significant factors that can bring about the competitive advantage's sustainability and superior performance, on the condition that the firm has specific characteristics. These resources have to be valuable, efficient and effective, rare, inimitable and nonsubstitutable (VRIN) (Barney, 1991). As such, a firm may be capable of sustaining its resources to make it stand out from its rivals in order to achieve success in a dynamic marketplace rife with competition (Amit \& Schoemaker, 1993; Carmeli \& Tishler, 2004; Collis \& Montgomery, 1998; Dierickx \& Cool, 1989).

To this end, organizational culture and leadership style may be considered as a unique intangible asset of the organization that influences its performance (Lo, 2012). Both culture and leadership styles are considered as the independent variables of this study, and their influence on the performance of organizations is the main aim of the study, with the help of RBV theory. The RBV theory is suitable for this study as it has been indicated by other prior studies that it adopts a specific organizational culture (bureaucratic, supportive, innovative) and a specific leadership style (transactional, transformational) and consider them as distinct resources that could assist the firm in obtaining competitive advantage and enhance performance (Lok \& Crawford, 2004; Ogbonna \& Harris, 2000).

Additionally, by achieving employee job satisfaction and motivating the affective commitment of employees, the organization may obtain tangible and intangible advantages (Oz, Derekoylu, Buyukbay \& Yildiz, 2013). The RBV theory was also employed by Qureshi, Hayat, Ali and Sarwat (2011) to examine the mediating impact of job satisfaction and organizational commitment on the leadership styles-organizational performance relationship. It was also used in the study conducted by Obradovich (2009) who focused on the leadership and culture influence on the U.S. troubled firms financial performance.

This article considers the QMPs implementation as one of the organizational efforts made to enhance the internal environmental processes to ensure optimum performance. Therefore, this article proposes that the systems theory is also suitable to be used to be the

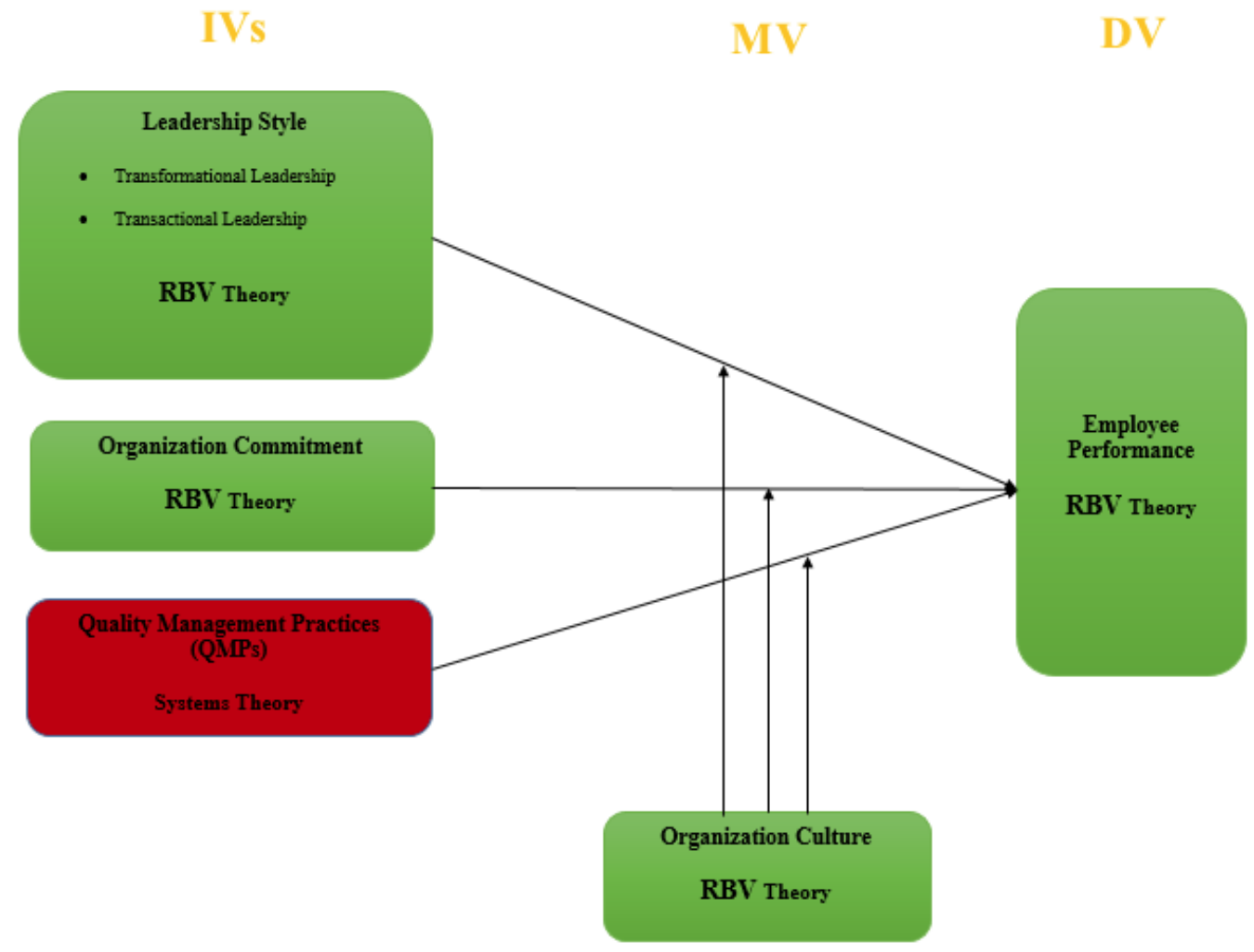

Figure 1: Theoretical Framework. 
underpinning theory. In sum, both the RBV theory and the systems theory are used by the researcher for the interpretation and explanation of the Jordanian hotels performance.

\section{CONCLUSION}

The reviewed studies in this article mainly pointed to the poor performance of majority of hotels but this does not seem to be significantly deviated from the service and manufacturing SMEs performance. Some of the firms that adopted performance style seem to have done so without direction and strategy and without integrating it to their business strategy. This matter is still ambiguous in the context of SMS as it may be that the good performance style adoption can lead to significant performance. In other words, it is not clear whether the adoption of performance style by itself can be deemed as performance.

Literature shows that performance may be beneficial, although this article only focused on larger organizations in the form of Jordanian hotels. In this regard, the link between quality management practices, commitment, leadership style and performance as promoted by organizational culture is still inconclusive. While this linkage is still tenuous, it can only be confirmed if future studies focus on larger businesses in the retail and financial services sector.

There is an evident need for studies relating to the hospitality sector and thus, this article recommends that future studies investigate the relationship between QMPs, commitment, leadership style and performance, with the organizational culture as the moderating variable. Also, particularly focus should be laid on the examination of factors that have the potential to bring about the employees' perception of 'concern for employee well-being'.

Finally, this article recommends future studies to carry out surveys by distributing questionnaires among five star hotels in Jordan, to determine the impact of the study variables on the employees' performance. This will have significant implications to hotel managers and the resolution of the issues they face in the sector.

\section{REFERENCES}

Abdul Rashid, Z., Sambasivan, M., \& Johari, J. (2003). The influence of corporate culture and organisational commitment on performance. Journal of Management Development, 22(8), 708-728. https://doi.org/10.1108/02621710310487873

Abdullah, N. H., Shamsuddin, A., Wahab, E., \& Hamid, N. A. A. (2014). The relationship between organizational culture and product innovativeness. Procedia-Social and Behavioral Sciences, 129, 140-147.

https://doi.org/10.1016/j.sbspro.2014.03.659

Alvesson, M., \& Sveningsson, S. (2015). Changing organizational culture: Cultural change work in progress: Routledge.

Amit, R., \& Schoemaker, P. (1993). Strategic assets and organizational rent. Strategic management journal, 14(1), 3346.

https://doi.org/10.1002/smj.4250140105

Ariyabuddhiphongs, V., \& Kahn, S. I. (2017). Transformational leadership and turnover intention: The mediating effects of trust and job performance on café employees in Thailand. Journal of Human Resources in Hospitality \& Tourism, 16(2), 215-233. https://doi.org/10.1080/15332845.2016.1202730

Assaf, A. G., \& Josiassen, A. (2016). Frontier analysis: A state-ofthe-art review and meta-analysis. Journal of travel research, 55(5), 612-627. https://doi.org/10.1177/0047287515569776

Assaf, A. G., Josiassen, A., \& Cvelbar, L. K. (2012). Does triple bottom line reporting improve hotel performance? International Journal of Hospitality Management, 31(2), 596600.

https://doi.org/10.1016/j.jhm.2011.08.005

Bacha, E. (2014). The relationship between transformational leadership, task performance and job characteristics. Journal of Management Development, 33(4), 410-420. https://doi.org/10.1108/JMD-02-2013-0025

Barney, J. (1986). Organizational culture: can it be a source of sustained competitive advantage? Academy of Management review, 11(3), 656-665. https://doi.org/10.2307/258317

Barney, J. (1991). Firm resources and sustained competitive advantage. Journal of management, 17(1), 99-120. https://doi.org/10.1177/014920639101700108

Bommer, W., Rubin, R., \& Baldwin, T. (2004). Setting the stage for effective leadership: Antecedents of transformational leadership behavior. The Leadership Quarterly, 15(2), 195210.

https://doi.org/10.1016/j.leaqua.2004.02.012

Brah, S., \& Ying Lim, H. (2006). The effects of technology and TQM on the performance of logistics companies. International Journal of Physical Distribution \& Logistics Management, 36(3), 192-209. https://doi.org/10.1108/09600030610661796

Bronkhorst, B., Steijn, B., \& Vermeeren, B. (2015). Transformational leadership, goal setting, and work motivation: The case of a Dutch municipality. Review of Public Personnel Administration, 35(2), 124-145. https://doi.org/10.1177/0734371X13515486

Bruch, H., \& Walter, F. (2007). Leadership in context: Investigating hierarchical impacts on transformational leadership. Leadership \& Organization Development Journal, 28(8), 710726. https://doi.org/10.1108/01437730710835452

Carmeli, A., \& Tishler, A. (2004). Resources, capabilities, and the performance of industrial firms: A multivariate analysis. Managerial and decision economics, 25(6-7), 299-315. https://doi.org/10.1002/mde.1192

Chen, W.-J. (2011). Innovation in hotel services: Culture and personality. International Journal of Hospitality Management, 30(1), 64-72. https://doi.org/10.1016/j.jhm.2010.07.006

Cheung, M., \& Wong, C.-S. (2011). Transformational leadership, leader support, and employee creativity. Leadership \& Organization Development Journal, 32(7), 656-672. https://doi.org/10.1108/01437731111169988

Chu, L.-C., \& Lai, C.-C. (2011). A research on the influence of leadership style and job characteristics on job performance 
among accountants of county and city government in Taiwan. Public Personnel Management, 40(2), 101-118. https://doi.org/10.1177/009102601104000202

Clarke, N. (2006). The relationships between network commitment, its antecedents and network performance. Management Decision, 44(9), 1183-1205.

https://doi.org/10.1108/00251740610707677

Collis, D., \& Montgomery, C. (1998). Corporate strategy: A resourcebased approach: Irwin/McGraw-Hill Boston, MA.

Dai, Y.-D., Dai, Y.-Y., Chen, K.-Y., \& Wu, H.-C. (2013). Transformational vs transactional leadership: which is better? A study on employees of international tourist hotels in Taipei City. International Journal of Contemporary Hospitality Management, 25(5), 760-778. https://doi.org/10.1108//JCHM-Dec-2011-0223

Deming, E. (1986). Out of The Crisis. Quality, Productivity and Competitive Position. Cambridge, MA: Center for Advanced Engineering Study: Cambridge University Press.

Denison, D. (1996). What is the difference between organizational culture and organizational climate? A native's point of view on a decade of paradigm wars. Academy of Management review, 21(3), 619-654.

Denison, D., \& Mishra, A. (1995). Toward a theory of organizational culture and effectiveness. Organization science, 6(2), 204223

https://doi.org/10.1287/orsc.6.2.204

Deshpandé, R., Farley, J., \& Webster Jr, F. (1993). Corporate culture, customer orientation, and innovativeness in Japanese firms: a quadrad analysis. The Journal of Marketing, 23-37. https://doi.org/10.2307/1252055

Dierickx, I., \& Cool, K. (1989). Asset stock accumulation and sustainability of competitive advantage. Management science, 35(12), 1504-1511. https://doi.org/10.1287/mnsc.35.12.1504

Dinçer, M. Z., \& Alrawadieh, Z. (2017). Negative Word of Mouse in the Hotel Industry: A Content Analysis of Online Reviews on Luxury Hotels in Jordan. Journal of Hospitality Marketing \& Management(just-accepted). https://doi.org/10.1080/19368623.2017.1320258

Elbaz, A. M., \& Haddoud, M. Y. (2017). The role of wisdom leadership in increasing job performance: Evidence from the Egyptian tourism sector. Tourism management, 63, 66-76. https://doi.org/10.1016/j.tourman.2017.06.008

Elnihewi, I. M. (2015). The Relationship Between Contingency And Institutional Factors, And Organisational Performance Through The Performance Measures Of Libyan Commercial Banks. (Doctor of Philosophy), UUM, Malaysia

Epitropaki, O., \& Martin, R. (2005). From ideal to real: a longitudinal study of the role of implicit leadership theories on leadermember exchanges and employee outcomes. Journal of Applied Psychology, 90(4), 659.

https://doi.org/10.1037/0021-9010.90.4.659

Feng, M., Terziovski, M., \& Samson, D. (2007). Relationship of ISO 9001: 2000 quality system certification with operational and business performance: A survey in Australia and New Zealand-based manufacturing and service companies. Journal of manufacturing technology management, 19(1), 2237. https://doi.org/10.1108/17410380810843435

Fort, A., \& Voltero, L. (2004). Factors affecting the performance of maternal health care providers in Armenia. Human resources for health, 2(1), 8. https://doi.org/10.1186/1478-4491-2-8

Gao, C. L. (2016). The relationship between training, work attitudes, leadership and job performance. Universiti Utara Malaysia.

Gordon, G., \& DiTomaso, N. (1992). Predicting corporate performance from organizational culture. Journal of Management Studies, 29(6), 783-798. https://doi.org/10.1111/j.1467-6486.1992.tb00689.x
Gregory, B., Harris, S., Armenakis, A., \& Shook, C. (2009) Organizational culture and effectiveness: A study of values, attitudes, and organizational outcomes. Journal of Business Research, 62(7), 673-679. https://doi.org/10.1016/j.jbusres.2008.05.021

Hartnell, C., Ou, A. Y., \& Kinicki, A. (2011). Organizational culture and organizational effectiveness: a meta-analytic investigation of the competing values framework's theoretical suppositions: American Psychological Association

Heras Saizarbitoria, I., Arana Landín, G., \& Casadesús Fa, M. (2006). The impact of quality management in European companies' performance: The case of the Spanish companies. European Business Review, 18(2), 114-131. https://doi.org/10.1108/09555340610651839

Herman, \& Chiu, W. (2014). Transformational leadership and job performance: A social identity perspective. Journal of Business Research, 67(1), 2827-2835. https://doi.org/10.1016/j.jbusres.2012.07.018

Heskett, J. L., \& Kotter, J. P. (1992). Corporate culture and performance. Business Review. Vol, 2, 83-93.

Isaac Mwita, J. (2000). Performance management model: A systemsbased approach to public service quality. International Journal of Public Sector Management, 13(1), 19-37. https://doi.org/10.1108/09513550010334461

Ivey, G., \& Kline, T. (2010). Transformational and active transactional leadership in the Canadian military. Leadership \& Organization Development Journal, 31(3), 246-262. https://doi.org/10.1108/01437731011039352

Jackson, P., \& Ashton, D. (1995). Managing a Quality System Using Bs/En/Iso 9000:(formerly BS 5750): Kogan Page.

Jyoti, J., \& Bhau, S. (2015). Impact of transformational leadership on job performance: Mediating role of leader-member exchange and relational identification. SAGE Open, 5(4), 2158244015612518 https://doi.org/10.1177/2158244015612518

Kemp, S., \& Dwyer, L. (2001). An examination of organisational culture-the Regent Hotel, Sydney. International Journal of Hospitality Management, 20(1), 77-93. https://doi.org/10.1016/S0278-4319(00)00045-1

Keskes, I. (2014). Relationship between leadership styles and dimensions of employee organizational commitment: A critical review and discussion of future directions. Intangible Capital, 10(1). https://doi.org/10.3926/ic.476

Kim Jean Lee, S., \& Yu, K. (2004). Corporate culture and organizational performance. Journal of Managerial Psychology, 19(4), 340-359. https://doi.org/10.1108/02683940410537927

Kumar, V., Choisne, F., de Grosbois, D., \& Kumar, U. (2009). Impact of TQM on company's performance. International Journal of Quality \& Reliability Management, 26(1), 23-37. https://doi.org/10.1108/02656710910924152

Kuranchie-Mensah, E. B., \& Amponsah-Tawiah, K. (2016). Employee motivation and work performance: A comparative study of mining companies in Ghana. Journal of industrial Engineering and Management, 9(2), 255. https://doi.org/10.3926/jiem.1530

Li, J.-H., Anderson, A., \& Harrison, R. (2003). Total quality management principles and practices in China. International Journal of Quality \& Reliability Management, 20(9), 10261050. https://doi.org/10.1108/02656710310500833

Liang, S.-g., \& Chi, S.-c. S. (2011). Follower affect linking transformational leadership to job performance: a cross-level analysis. Paper presented at the Academy of Management Proceedings. https://doi.org/10.5465/AMBPP.2011.65869724

Liu, J., Liu, X., \& Zeng, X. (2011). Does transactional leadership count for team innovativeness? The moderating role of 
emotional labor and the mediating role of team efficacy. Journal of Organizational Change Management, 24(3), 282298. https://doi.org/10.1108/09534811111132695

Lo, Y.-H. (2012). Back to hotel strategic management 101: An examination of hotel's implementation of Porter's generic strategy in China. The Journal of International Management Studies, 7(1), 56-69.

Lok, P., \& Crawford, J. (2004). The effect of organisational culture and leadership style on job satisfaction and organisational commitment: A cross-national comparison. Journal of Management Development, 23(4), 321-338. https://doi.org/10.1108/02621710410529785

Malmadana Kapuge, A., \& Smith, M. (2007). Management practices and performance reporting in the Sri Lankan apparel sector. Managerial Auditing Journal, 22(3), 303-318. https://doi.org/10.1108/02686900710733161

Martínez-Costa, M., \& Martínez-Lorente, Á. R. (2007). A triple analysis of ISO 9000 effects on company performance. International Journal of Productivity and Performance Management, 56(5/6), 484-499.

https://doi.org/10.1108/17410400710757150

McConnell, C. (2003). The manager's approach to employee performance problems. The health care manager, 22(1), 63-69. https://doi.org/10.1097/00126450-200301000-00011

Meyer, J., \& Allen, N. (1984). Testing the" side-bet theory" of organizational commitment: Some methodological considerations. Journal of Applied Psychology, 69(3), 372. https://doi.org/10.1037/0021-9010.69.3.372

Navanitham, T. M. (2016). The relationship between work-life balance, job satisfaction and job performance. Universiti Utara Malaysia.

Newland, A., Newton, M., Podlog, L., Legg, W. E., \& Tanner, P. (2015). Exploring the nature of transformational leadership in sports: a phenomenological examination with female athletes. Qualitative Research in Sport, Exercise and Health, 7(5), 663-687. https://doi.org/10.1080/2159676X.2015.1007889

Nor Hidayah, I. (2016). Social media usage, leadership style and job performance among administrative officers of Universiti Utara Malaysia. Universiti Utara Malaysia.

Obiwuru, T., Okwu, A., Akpa, V., \& Nwankwere, I. (2011). Effects of leadership style on organizational performance: A survey of selected small scale enterprises in Ikosi-Ketu council development area of Lagos State, Nigeria. Australian Journal of Business and Management Research, 1(7), 100.

Obradovich, J. (2009). Influence of leadership and culture on financial performance: A case study in a troubled industry. Capella University.

Ogbonna, E., \& Harris, L. (2000). Leadership style, organizational culture and performance: empirical evidence from UK companies. International Journal of Human Resource Management, 11(4), 766-788. https://doi.org/10.1080/09585190050075114

Omar, W. W. (2013). Transformational leadership style and job satisfaction relationship: A study of structural equation modeling (SEM). International Journal of Academic Research in Business and Social Sciences, 3(2), 346. https://doi.org/10.1108/01437730110410071

Öz, E. Ü., Dereköylü, T., Büyükbay, Ş. E., \& Yildiz, D. (2013). what has job satisfaction got to do with employee commitment? a research study on Imx and work attitudes.

Pavia, N., Grzinic, J., \& Floricic, T. (2014). Specialisation as a trend in modern hotel industry. Paper presented at the Faculty of Tourism and Hospitality Management in Opatija. Biennial International Congress. Tourism \& Hospitality Industry.

Politis, J. (2001). The relationship of various leadership styles to knowledge management. Leadership \& Organization Development Journal, 22(8), 354-364.
Popovich, M., \& Brizius, J. (1998). Creating high-performance government organizations: a practical guide for public managers: Jossey-Bass Inc Pub.

Qureshi, J. A., Hayat, K., Ali, M., \& Sarwat, N. (2011). Impact of job satisfaction and organizational commitment on employee performance, evidence from Pakistan. Interdisciplinary Journal of Contemporary Research in Business, 3(4), 642657.

Ravichandran, S., \& Gilmore, S. (2007). Formation of organizational citizenship behaviors in students employed in university dining services: impact of manager and co-worker behaviors. Journal of Foodservice Business Research, 10(2), 19-50. https://doi.org/10.1300/J369v10n02 03

Romle, A. R. (2014). An examination of quality management practices, human-oriented elements, and organizational performance in the Malaysian higher education institutions. Universiti Utara Malaysia.

Rowold, J., Borgmann, L., \& Bormann, K. (2014). Which leadership constructs are important for predicting job satisfaction, affective commitment, and perceived job performance in profit versus nonprofit organizations? Nonprofit Management and Leadership, 25(2), 147-164. https://doi.org/10.1002/nml.21116

Rowold, J., \& Schlotz, W. (2009). Transformational and transactional leadership and followers' chronic stress. Leadership Review, 9(1), 35-48.

Rumelt, R. (1987). Theory, strategy, and entrepreneurship. The competitive challenge, 137, 158.

Sani, A., \& Maharani, V. (2012). The impacts of transformational leadership and organizational commitment on job performance with the among lecturers of faculty in the Islamic Maulana Malik Ibrahim Malang University: The mediating effects of organizational citizenship behavior. International Journal of Academic Research, 4(4), 102-106. https://doi.org/10.7813/2075-4124.2012/4-4/B.15

Sarros, J. C., \& Santora, J. C. (2001). The transformationaltransactional leadership model in practice. Leadership \& Organization Development Journal, 22(8), 383-394. https://doi.org/10.1108/01437730110410107

Schein, E. (2010). Organizational culture and leadership (Vol. 2): John Wiley \& Sons.

Shahzad, F., Luqman, R. A., Khan, A. R., \& Shabbir, L. (2012). Impact of organizational culture on organizational performance: An overview. Interdisciplinary Journal of Contemporary Research in Business, 3(9), 975-985.

Sila, I. (2007). Examining the effects of contextual factors on TQM and performance through the lens of organizational theories: An empirical study. Journal of Operations Management, 25(1), 83-109. https://doi.org/10.1016/j.jom.2006.02.003

Tajeddini, K., \& Trueman, M. (2012). Managing Swiss Hospitality: How cultural antecedents of innovation and customeroriented value systems can influence performance in the hotel industry. International Journal of Hospitality Management, 31(4), 1119-1129. https://doi.org/10.1016/j.ijhm.2012.01.009

Umrani, W. A. (2016). Moderating effect of organizational culture on the relationship between corporate entrepreneurship and business performance in Pakistan's banking sector. Universiti Utara Malaysia.

Vito, G., Higgins, G., \& Denney, A. (2014). Transactional and transformational leadership: An examination of the leadership challenge model. Policing: An International Journal of Police Strategies \& Management, 37(4), 809-822. https://doi.org/10.1108/PIJPSM-01-2014-0008

Wahab, A. (2016). Factors determining perceived job performance of University leaders in Pakistan. Universiti Utara Malaysia.

Wang, C.-H., Chen, K.-Y., \& Chen, S.-C. (2012). Total quality management, market orientation and hotel performance: The 
moderating effects of external environmental factors. International Journal of Hospitality Management, 31(1), 119129. https://doi.org/10.1016/j.ijhm.2011.03.013

Wernerfelt, B. (1984). A resource-based view of the firm. Strategic management journal, 5(2), 171-180. https://doi.org/10.1002/smj.4250050207

Wright, T., \& Bonett, D. (2002). The moderating effects of employee tenure on the relation between organizational commitment and job performance: a meta-analysis. Journal of Applied Psychology, 87(6), 1183. https://doi.org/10.1037/0021-9010.87.6.1183

Wunderlich, N., \& Beck, R. (2017). Time for Climate Change: Leadership, IT Climate, and their Impact on Organizational Performance. Paper presented at the Proceedings of the 50th Hawaii International Conference on System Sciences. https://doi.org/10.24251/HICSS.2017.611

Yang, Y., Wong, K. K., \& Wang, T. (2012). How do hotels choose their location? Evidence from hotels in Beijing. International Journal of Hospitality Management, 31(3), 675-685. https://doi.org/10.1016/j.ijhm.2011.09.003

Yasin, M., Alavi, J., Kunt, M., \& Zimmerer, T. (2004). TQM practices in service organizations: an exploratory study into the implementation, outcome and effectiveness. Managing Service Quality: An International Journal, 14(5), 377-389. https://doi.org/10.1108/09604520410557985

Yuan, F., \& Woodman, R. (2010). Innovative behavior in the workplace: The role of performance and image outcome expectations. Academy of Management Journal, 53(2), 323342.

https://doi.org/10.5465/AMJ.2010.49388995

Zervas, G., Proserpio, D., \& Byers, J. W. (2014). The rise of the sharing economy: Estimating the impact of Airbnb on the hotel industry. Journal of marketing research.

Zhang, Y., LePine, J., Buckman, B., \& Wei, F. (2014). It's not fair... or is it? The role of justice and leadership in explaining work stressor-job performance relationships. Academy of Management Journal, 57(3), 675-697. https://doi.org/10.5465/amj.2011.1110

Zhang, Y., Waldman, D., Han, Y.-L., \& Li, X.-B. (2015). Paradoxical leader behaviors in people management: Antecedents and consequences. Academy of Management Journal, 58(2), 538-566. https://doi.org/10.5465/amj.2012.0995

Received on 15-11-2017

DOI: https://doi.org/10.6000/1929-7092.2017.06.49

(C) 2017 Ghaith et al.; Licensee Lifescience Global.

This is an open access article licensed under the terms of the Creative Commons Attribution Non-Commercial License (http://creativecommons.org/licenses/by-nc/3.0/) which permits unrestricted, non-commercial use, distribution and reproduction in any medium, provided the work is properly cited. 